\title{
Asymmetric siRNA targeting the bcl-2 gene inhibits the proliferation of cancer cells in vitro and in vivo
}

\author{
YAN YIN $^{1}$, XU CHEN $^{1}$, CHANG-DONG ZHANG $^{1}$, PEI-FENG LIU ${ }^{2}$, YOU-RONG DUAN ${ }^{2}$, YAN-RONG FAN ${ }^{3}$, \\ ZHI-WEI WU ${ }^{4}$, GENG-FENG FU ${ }^{5}$, JIAN-JUN WANG ${ }^{1}$ and GEN-XING XU $\mathrm{XU}^{4,6}$ \\ ${ }^{1}$ Department of Biological Science and Technology and State Key Laboratory of Pharmaceutical Biotechnology, \\ School of Life Sciences, Nanjing University, Nanjing 210093; ${ }^{2}$ Shanghai Cancer Institute, Renji Hospital, \\ Shanghai Jiao Tong University School of Medicine, Shanghai 200032; ${ }^{3}$ School of Chemical Engineering, \\ Nanjing University of Science and Technology, Nanjing 210094; ${ }^{4}$ Center for Public Health Research, \\ Medical School and State Key Laboratory of Analytical Chemistry for Life Science, Nanjing University, \\ Nanjing 210093; ${ }^{5}$ Jiangsu Provincial Center for Disease Prevention and Control, Nanjing 210009; \\ ${ }^{6}$ Jiangsu Research Center for Gene Pharmaceutical Engineering and Technology, Suzhou 215128, P.R. China
}

Received August 19, 2012; Accepted October 11, 2012

DOI: 10.3892/ijo.2012.1691

\begin{abstract}
Small interfering RNAs (siRNAs) are valuable reagents for efficient gene silencing in a sequence-specific manner via the RNA interference (RNAi) pathway. The current synthetic siRNA structure consists of symmetrical duplexes of 19-21 base pairs (bp) with 2 nucleotide (nt) 3' overhangs. In this study, we report that an asymmetric siRNA (asiRNA) consisting of $17 \mathrm{bp}$ duplex region (17 bp asiRNA) exhibited potent activity in inhibiting bcl-2 gene expression and cancer cell proliferation in vitro. Importantly, this asiRNA structure significantly reduced off-target silencing by the sense strand. To improve the stability of the $17 \mathrm{bp}$ asiRNA, we synthesized a series of chemically modified 17 bp asiRNAs. Further experiments showed that in comparison with the $17 \mathrm{bp}$ asiRNA, the $17 \mathrm{bp}$ asiRNA-M2, one of the modified 17 bp asiRNAs, exhibited a comparable gene silencing activity and an improved stability in vitro. Furthermore, the 17 bp asiRNA-M2 with a proteolipid micelle delivery system can effectively suppress the growth of $\mathrm{H} 22$ and BGC 803 tumors in vivo. These results suggest that the chemically modified asiRNAs may have potential as an effective therapeutic approach for cancer gene therapy in the future.
\end{abstract}

Correspondence to: Professor Gen-Xing Xu, Center for Public Health Research, Medical School, Nanjing University, 22 Hankou Road, Nanjing 210093, P.R. China

E-mail: genxingxu@nju.edu.cn

Professor Jian-Jun Wang, School of Life Sciences, Mailbox 426, Nanjing University, 22 Hankou Road, Nanjing 210093, P.R. China E-mail: jjwang@nju.edu.cn

Key words: small interfering RNAs, asymmetric siRNA, bcl-2, cancer gene therapy

\section{Introduction}

The Bcl-2 family proteins are central regulators of programmed cell death (1). Among the family, Bcl-2 is capable of inhibiting cell apoptosis and is overexpressed in several types of cancer, such as lung, breast, gastrointestinal and bladder cancer (2-7). Therefore, the inhibition of $\mathrm{Bcl}-2$ protein expression is an attractive strategy for cancer gene therapy.

RNA interference (RNAi) is a powerful method to specifically suppress the expression of target genes in a homology-dependent manner and is therefore widely used for experimental as well as therapeutic purposes. Current RNAi technology usually relies on small interfering RNA (siRNA) consisting of symmetrical and complementary duplexes of 19-21 base pairs (bp) with 2 nucleotide (nt) 3 ' overhangs $(8,9)$. However, this siRNA structure triggers several non-specific effects posing challenges to the application of RNAi therapeutics in clinical practice $(10,11)$. Recent studies have shown that the asymmetric RNA duplexes are capable of effectively silencing target gene expressions (12-14). The asymmetric siRNA (asiRNA), similar to siRNA, is incorporated into the RNA-induced silencing complex (RISC) and mediates the sequence-specific cleavage of the target mRNA. In addition, asiRNA can reduce off-target silencing by the sense strand and reduce the saturation of the cellular RNAi machinery. Compared with conventional siRNA, asiRNA possesses certain advantages in RNAi. However, whether asiRNA targeting the bcl-2 gene can effectively silence the target gene expression has not yet been investigated.

The poor stability and inefficient delivery of siRNA are two major obstacles for the therapeutic application of siRNA following systemic administration. Chemical modification is an effective method for improving the stability of siRNA and several studies have reported that some siRNAs with chemical modifications show durable activities in RNAi assays (15-17). To effectively deliver siRNA in vivo, various delivery systems have been developed, including lipids, polymers and nanoparticles, with varying degrees of success (18-20). 
Our previous study demonstrated that siRNA targeting bcl-2 inhibited gene expression and induced the apoptosis of tumor cells in vitro and in vivo (21). In the present study, we synthesized a series of asiRNAs ranging from the 13-17 bp duplex region (13-17 bp asiRNAs) targeting bcl-2 and evaluated their activities in cancer cells. The results showed that $17 \mathrm{bp}$ asiRNA had potent activity in downregulating bcl-2 gene expression and inhibiting tumor proliferation in vitro. Furthermore, chemically modified 17 bp asiRNA improved the stability of the molecule and effectively inhibited tumor growth in vivo when delivered through proteolipid micelles.

\section{Materials and methods}

Design and synthesis of siRNA and asiRNAs. The siRNA sequence targeting the bcl-2 gene was selected from GenBank (accession no. M14745, nt sequences 607-625). This sequence was shown to significantly suppress bcl-2 gene expression in our previous study (21). The structures of the asiRNAs consisted of duplex strands ranging from 13-17 bp. The $17 \mathrm{bp}$ asiRNA was chemically modified with cholesterol, 2'-O-methylation (2'-O-Me), 2'-fluoro-uridine (2'-FU) and phosphorothioate and was termed M1-M7. All the siRNA, asiRNAs and chemically modified asiRNAs were synthesized and purified by RiboBio Co. Ltd. (Guangzhou, China). The siRNA and asiRNAs were dissolved in sterilized and RNase-free water to a final concentration of $20 \mu \mathrm{M}$.

Animals and tumor cells. Male BABL/c nude mice (grade SPF, 18-20 g), male and female ICR mice (grade SPF, 19-21 g) were purchased from the Shanghai Laboratory Animal Center (Shanghai, China). Male Kunming mice, aged 6-8 weeks $(20 \pm 2 \mathrm{~g})$, were obtained from the Qinglongshan Animal Center (Nanjing, China). The animals were maintained in accordance with the US National Institutes of Health Guide for the Care and Use of Laboratory Animals (NIH Publication 80-23, revised 1996) and the experimental protocols were approved by the Nanjing University Animal Care and Use Committee. All efforts were made to minimize the number of animals used and their suffering.

HeLa B2 cell lines which expressed high levels of Bcl-2 protein were kindly provided by Professor Chen Lin (Cell Center of Chinese Academy of Military Medicine, Beijing, China) and were used to evaluate the siRNA suppression of bcl-2 gene expression in vitro. The cell lines were cultured in Dulbecco's modified Eagle's medium (DMEM) with high glucose supplemented with $10 \%$ fetal bovine serum (FBS, Gibco-BRL), $100 \mathrm{U} / \mathrm{ml}$ penicillin and $100 \mu \mathrm{g} / \mathrm{ml}$ streptomycin in $5 \% \mathrm{CO}_{2}$ at $37^{\circ} \mathrm{C}$. The HuH-7 human hepatoma cell line was provided by the Shanghai Cancer Institute (Shanghai, China). H22 murine hepatoma cells were supplied by the Shanghai Academy of Medical Industry (Shanghai, China). BGC 803 gastric cancer cells were obtained from Jiangsu Provincial Institute of Materia Medica (Nanjing, China).

Cell transfection. One day prior to transfection, HeLa B2 cells were seeded in $2 \mathrm{ml}$ of complete medium without antibiotics in a 6-well plate so that the cells reached $30-50 \%$ confluency at the time of transfection. A total $5 \mu \mathrm{l}$ of siRNA or asiRNA $(20 \mu \mathrm{M}$ stock) was added to $250 \mu \mathrm{l}$ of Opti-MEM (Invitrogen, Carlsbad,
CA, USA), and $2.5 \mu \mathrm{l}$ of Lipofectamine 2000 (Invitrogen) was diluted in the same amount of medium. After incubation for $5 \mathrm{~min}$ at room temperature, the diluted siRNA or asiRNA were mixed gently with the diluted Lipofectamine 2000, and incubated for $20 \mathrm{~min}$ at room temperature. The mixture was then added to the plates with $1.5 \mathrm{ml}$ of serum-free and antibiotic-free DMEM. The final concentration of siRNA or asiRNA was $33 \mathrm{nM}$.

Quantitative real-time RT-PCR ( $q R T-P C R)$. HeLa B2 cells transfected with $33 \mathrm{nM}$ siRNA or asiRNA were harvested $48 \mathrm{~h}$ after transfection. Total RNA was isolated using TRIzol reagent (Invitrogen) according to the manufacturer's instructions. The cDNA was synthesized using the PrimeScript RT reagent kit (Takara Bio Inc., Shiga, Japan) followed by diluting the concentration of the reverse transcription products to 1:20. qRT-PCR was performed using SYBR-Green real-time PCR master mix according to the manufacturer's instructions in a 7300 real-time PCR system (Applied Biosystems, Carlsbad, CA, USA). The PCR reaction program was as follows: $1 \mathrm{~min}$ at $95^{\circ} \mathrm{C}$ followed by 40 cycles of $15 \mathrm{sec}$ at $95^{\circ} \mathrm{C}, 15 \mathrm{sec}$ at $57^{\circ} \mathrm{C}$ and $45 \mathrm{sec}$ at $72^{\circ} \mathrm{C}$. $\beta$-actin was used as the internal control. The sequences of the specific primers were: 5'-GGTCATGTGTGTGGAGAGC-3' (forward) and 5'-GATCCAGGTGTGCAGGTG-3' (reverse) for bcl-2; 5'-AGTTGCGTTACACCCTTTC-3' (forward) and 5'-CCT TCACCGTTCCAGTTT-3' (reverse) for $\beta$-actin. The data were analyzed using 7300 system SDS software v1.3.3. The relative levels of individual mRNA transcripts to the control $\beta$-actin were calculated using the $2^{-\Delta \Delta C t}$ method. All experiments were carried out in triplicate.

Flow cytometric analysis. The relative expression levels of the $\mathrm{Bcl}-2$ protein in HeLa B2 cells treated with siRNA or asiRNA were detected by flow cytometry. HeLa B2 cells transfected with $33 \mathrm{nM}$ siRNA or asiRNA were harvested $72 \mathrm{~h}$ later and fixed with $4 \%$ paraformaldehyde (PFA) for $20 \mathrm{~min}$, followed by washing once with PBS. Subsequently, $0.1 \%$ saponin was added and incubated for $15 \mathrm{~min}$ before the cells were stained with PE conjugated mouse anti-human bcl-2 monoclonal antibody (BD Biosciences, Franklin Lakes, NJ, USA) at $4^{\circ} \mathrm{C}$ for $30 \mathrm{~min}$. Cells were analyzed by the BD FACS Arial Flow Cytometer and data were collected using BD FACSDiva software (BD Biosciences).

Cell proliferation assay. The effect of siRNA or asiRNA on the proliferation of HeLa B2 cells was measured using the Cell Counting Kit-8 (CCK-8). HeLa B2 cells were plated in 96-well microplates and transfected with $33 \mathrm{nM}$ siRNA or asiRNA. The medium was replaced with $100 \mu 1$ fresh DMEM together with $10 \mu \mathrm{l}$ CCK-8 (Dojindo, Kunamoto, Japan) per well $72 \mathrm{~h}$ after the transfection. After incubating the microplate at $37^{\circ} \mathrm{C}$ with $5 \% \mathrm{CO}_{2}$ for $2 \mathrm{~h}$, the absorbance at $450 \mathrm{~nm}$ was measured using a microplate reader (Atobio Diagnostics Co. Ltd., Zhengzhou, China). The cell viability (\%) was calculated using the following equation:

$$
\text { cell viability }(\%)=\frac{A_{s}-A_{b}}{A_{c}-A_{b}} \times 100
$$

$A_{s}$ is the absorbance measurement from a well treated with siRNA or asiRNA transfection samples, $A_{c}$ is the absorbance 
measurement from a well treated with transfection reagent and $\mathrm{A}_{\mathrm{b}}$ is the absorbance measurement from a blank well.

EGFP reporter assay. DNA oligonucleotides corresponding to the sense and antisense strands of siRNA targeting bcl-2 were cloned into the 3' untranslated region of the pEGFP-C1 plasmid (Clontech Laboratories, Mountain View, CA, USA) by PCR. The DNA oligonucleotide sequences were as follows: $\mathrm{Bcl}-2$ sense target, 5'-AAAGGCATCCCAGCCTCCG-3', 3'-TTTC CGTAGGGTCGGAGGC-5'; Bcl-2 antisense target, 5'-CGGA GGCTGGGATGCCTTT-3', 3'-GCCTCCGACCCTACGG AAA-5'.

Serum stability assay in vitro. For the stability assay, $2 \mu 1$ (40 pmol) of $17 \mathrm{bp}$ asiRNA or chemically modified $17 \mathrm{bp}$ asiRNA-M2 were incubated in $8 \mu \mathrm{l}$ of FBS for $2,4,8$ and $24 \mathrm{~h}$ at $37^{\circ} \mathrm{C}$, respectively. At different time-points, $2 \mu \mathrm{l}$ loading buffer was added and $10 \mu \mathrm{l}$ of each sample was loaded onto a $2 \%$ agarose gel followed by ethidium bromide staining. Equal amounts of asiRNA prior to serum incubation $(0 \mathrm{~h})$ were loaded as the control.

In vivo bio-distribution assay. In all the in vivo experiments carried out in this study, a proteolipid micelle was used to deliver asiRNA. The proteolipid micelle (termed PDE) was composed of polyethylene glycol-phosphatidylethanolamine (PEG-PE), phospholipid dioleylphosphatidylserine (DOPS) and rh-endostatin. The preparation and characterization of PDE were described in our previous study (22). The asiRNA/PDE complexes were prepared freshly and the mass ratio of asiRNA, rh-endostatin, PEG-PE and DOPS was 1:10:2.5:2.5. BABL/c nude mice were inoculated with $\mathrm{HuH}-7$ hepatocarcinoma cells $\left(3 \times 10^{6}\right.$ cells $\left./ 0.2 \mathrm{ml}\right)$ into the right flank subcutaneously. When the tumor size grew to $150 \mathrm{~mm}^{3}$, the mice were administered a single injection of $300 \mu$ l Cy5.5-labeled naked 17 bp asiRNA-M2 (40 $\mu \mathrm{g} /$ mouse) or Cy5.5-labeled 17 bp asiRNA-M2 (40 $\mu \mathrm{g} /$ mouse)/PDE complexes via the tail vein, respectively. The mice were anesthetized and photographed using the in vivo imaging system (Maestro, Cambridge Research \& Instrumentation Inc., Woburn, MA, USA) at 1, 12, 24 and $48 \mathrm{~h}$. At 1 and $24 \mathrm{~h}$, the mice were sacrificed and the major tissues and tumors were excised and imaged using the in vivo imaging system. The fluorescence intensities in the excised organs and tumors were quantified by the analysis software of the in vivo imaging system.

In vivo tumor models. The $\mathrm{H} 22$ hepatoma cell lines and BGC 803 gastric cancer cell lines were chosen for the evaluation of the effect of asiRNA on tumor inhibition in vivo. The H22 tumor model was established by a subcutaneous injection of H22 tumor cells $\left(1 \times 10^{6}\right.$ cells $\left./ 0.2 \mathrm{ml}\right)$ into the right flank of Kunming mice. The mice were weighed and divided randomly into five groups (ten per group) $24 \mathrm{~h}$ after inoculation (day 0). The mice in each group were injected with normal saline [0.4 ml, intravenously (i.v.), on days 1-14], $30 \mathrm{mg} / \mathrm{kg}$ CTX [intraperitonealy (i.p.), on days 1-7], naked 17 bp asiRNA-M2 (1 mg/kg asiRNA, $0.4 \mathrm{ml}$, i.v., on days 1-14), PDE (0.4 ml, i.v., on days 1-14), or $17 \mathrm{bp}$ asiRNA-M2/PDE complex $(1 \mathrm{mg} / \mathrm{kg}$ asiRNA, $0.4 \mathrm{ml}$, i.v., on days 1-14). The tumors were assessed every five days for up to 20 days post-treatment using calipers. The volumes of the tumors was calculated using the formula: tumor volume $=(\text { width })^{2} \mathrm{x}$ length $\mathrm{x} 0.52$. The BGC 803 gastric tumor model was established by a subcutaneous injection of BGC 803 tumor cells ( $1 \times 10^{6}$ cells $\left./ 0.2 \mathrm{ml}\right)$ into the right flank of $\mathrm{BLBA} / \mathrm{c}$ nude mice. When the tumor volume reached approximately $5 \mathrm{~mm}^{3}$, the nude mice were divided randomly into four groups (six per group), and injected with normal saline, CTX, PDE and 17 bp asiRNA-M2/PDE complex, respectively, as mentioned above. The mice were sacrificed on day 18 and the tumors were excised, weighed and measured. The tumor growth inhibition rate (IR) was determined by the following formula:

tumor weight/volume of control group tumor weight/volume of treatment group

tumor weight/volume of control group

Statistical analysis. The data are presented as the means \pm SD. The difference among groups was analyzed by one-way ANOVA and using the Student's t-test in both groups and the ANOVA test in multiple groups. The comparisons between multiple groups were performed using the Student-NewmanKeuls (SNK) q-test. P-values $<0.05$ were considered to indicate statistically significant differences.

\section{Results}

Silencing bcl-2 gene expression by siRNA or asiRNAs. In order to compare the gene silencing activity of siRNA and asiRNAs, a series of asiRNAs with the sense strand from 13 to $17 \mathrm{nt}$ with 2 nt 3 ' overhangs (dTdT) were designed, and the antisense strand contained 19 nt with 2 nt 3' overhangs (Fig. 1A). These asymmetrical siRNAs were termed 13-17 bp asiRNAs.

The effect of siRNA or asiRNAs on the downregulation of bcl-2 mRNA expression was determined by qRT-PCR. As shown in Fig. 1B, the relative levels of bcl-2 mRNA were reduced by approximately 65 and $60 \%$ by 17 bp asiRNA and siRNA, respectively, while the relative levels of bcl-2 mRNA from the cells treated with 13-16 bp asiRNAs were reduced by approximately $20 \%$ compared with the control group. Though all the siRNA and asiRNAs inhibited bcl-2 mRNA expression, $17 \mathrm{bp}$ asiRNA was the most effective.

Flow cytometric analysis was performed to measure the Bcl-2 protein expression levels. As shown in Fig. 1C, the relative levels of Bcl-2 protein from the cells treated with 13-17 bp asiRNAs and siRNA were reduced by 35, 44, 52, 54, 76 and $68 \%$, respectively. Consistent with the downregulation of bcl-2 mRNA levels, 17 bp asiRNA downregulated Bcl-2 protein expressions the most efficaciously. These results demonstrated that 17 bp asiRNA targeting bcl- 2 exhibited more potent gene silencing activity than that of conventional siRNA.

Inhibition of cell proliferation by siRNA or asiRNAs. The effect of siRNA or asiRNAs on the proliferation of HeLa B2 cells was determined using CCK-8. As shown in Fig. 1D, 13-16 bp asiRNAs did not inhibit the cell proliferation while 17 bp asiRNA and siRNA had a significant inhibitory effect $(\mathrm{P}<0.05)$, with a 40 and $32 \%$ IR, respectively. The results demonstrated that $17 \mathrm{bp}$ asiRNA targeting bcl- 2 exhibited a cell proliferation inhibition activity comparable to that of the conventional siRNA. 
A
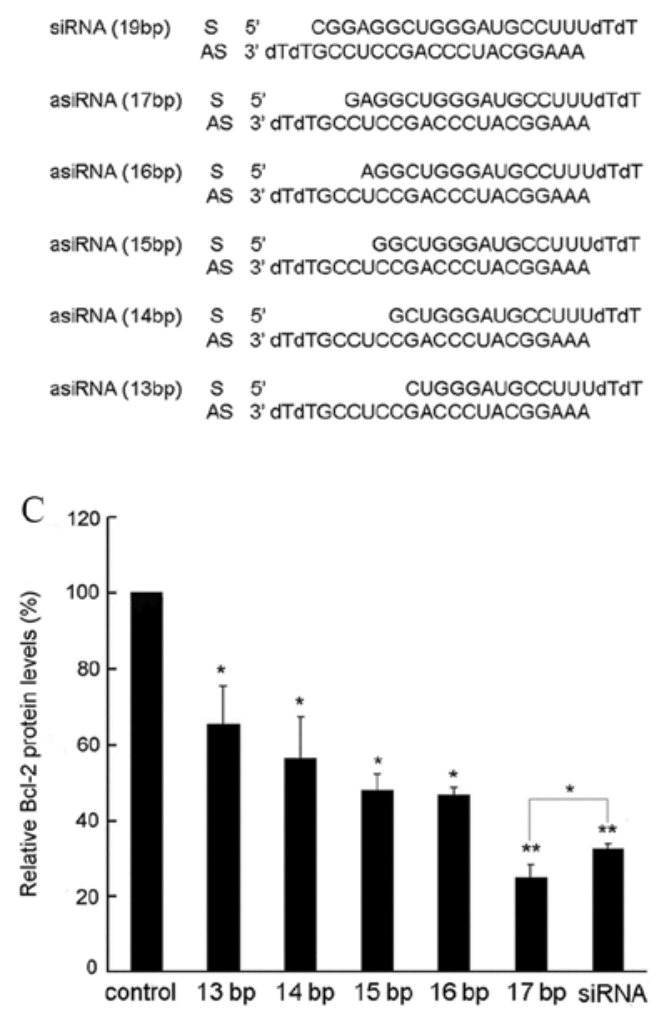
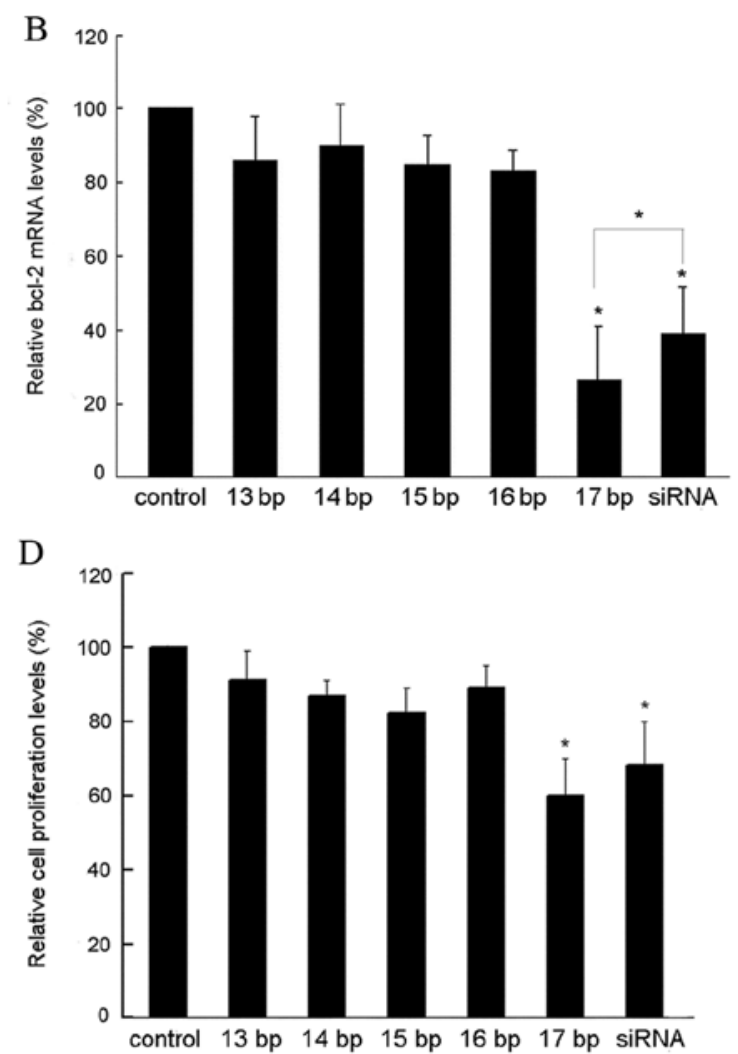

Figure 1. Effect of siRNA and asiRNAs on silencing bcl-2 expression and inhibiting the proliferation of HeLa B2 cells in vitro. (A) The sequences of siRNA and asiRNAs targeting bcl-2. (B) Bcl-2 mRNA expression level in HeLa B2 cells transfected with siRNA or asiRNAs. The relative levels of bcl-2 mRNA to control $\beta$-actin were determined by qRT-PCR. (C) Effect of siRNA and asiRNAs on bcl-2 protein expression levels in HeLa B2 cells. The relative bcl-2 protein levels were determined by flow cytometric analysis. (D) The siRNA and asiRNAs targeting bcl-2 inhibited the proliferation of HeLa B2 cells. The cell viabilities were determined by CCK-8 assay. All data in the graph represent the mean \pm SD values of three independent experiments. The control group was cells only treated with transfection reagent. ${ }^{*} \mathrm{P}<0.05 ;{ }^{* *} \mathrm{P}<0.01$.

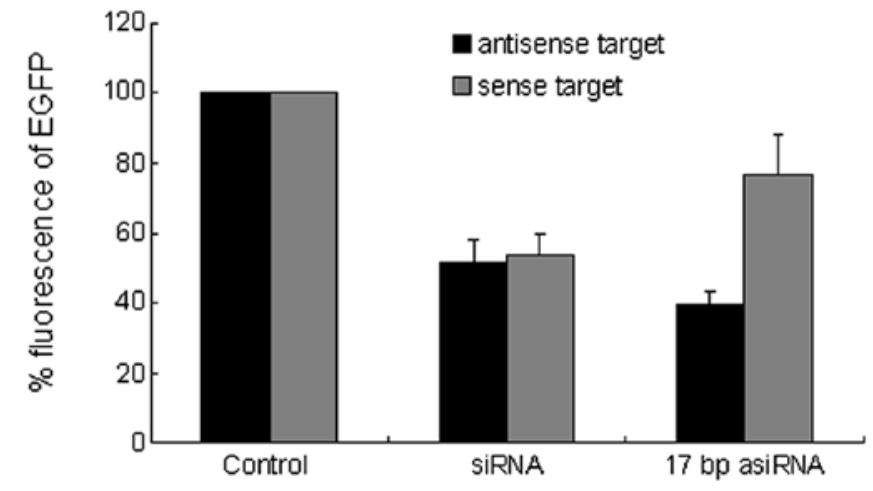

Figure 2. Reduced sense strand-mediated off-target gene silencing by asiRNA. HeLa cells were transfected with the EGFP reporter plasmid containing the antisense or sense target sequence with or without siRNA or $17 \mathrm{bp}$ asiRNA targeting bcl-2. EGFP expression was measured $48 \mathrm{~h}$ after transfection by flow cytometry.

asiRNA reduces off-target silencing activity. Several studies have demonstrated that asymmetric RNA structure significantly reduces off-target silencing by the sense strand $(12,13)$. To investigate whether asiRNA targeting bcl-2 also reduces off-target silencing mediated by the sense strand, we constructed an expression plasmid encoding EGFP mRNA containing either the sense or antisense sequence of bcl-2 in the $3^{\prime}$ untranslated region. The EGFP expression plasmid and siRNA or $17 \mathrm{bp}$ asiRNA were then co-transfected into HeLa cells and EGFP expression was analyzed by flow cytometry. Both siRNA and asiRNA showed strong silencing activity toward the antisense target. siRNA exhibited a silencing effect toward the sense target, while $17 \mathrm{bp}$ asiRNA significantly reduced silencing activity toward the sense target (Fig. 2). These results demonstrated that $17 \mathrm{bp}$ asiRNAs targeting bcl-2 reduced off-target silencing activity mediated by the sense strand.

Downregulation of bcl-2 expression by chemically modified $17 \mathrm{bp}$ asiRNA. As $17 \mathrm{bp}$ asiRNA was shown to have potent gene silencing activity, we further investigated this effect with different chemical modifications and selected a stable and active modified 17 bp asiRNA for in vivo study. The $17 \mathrm{bp}$ asiRNA was chemically modified with partial phosphorothioate backbone, 2'-O-Me and 2'-FU on the sense or antisense strands, and the 5 ' end of sense strands were all conjugated with a cholesterol molecule. These chemically modified $17 \mathrm{bp}$ asiRNAs were termed M1-M7. The detailed modification methods and sequences are shown in Fig. 3A. The efficacy of individual chemically modified $17 \mathrm{bp}$ asiRNA in downregulating the expression of $\mathrm{Bcl}-2$ protein was determined by flow cytometric assay. As shown in Fig. 3B, the IRs of Bcl-2 protein expression in the cells treated with modified asiRNAs M1-M7 were generally lower than those of the original asiRNA, and $17 \mathrm{bp}$ asiRNA-M2 

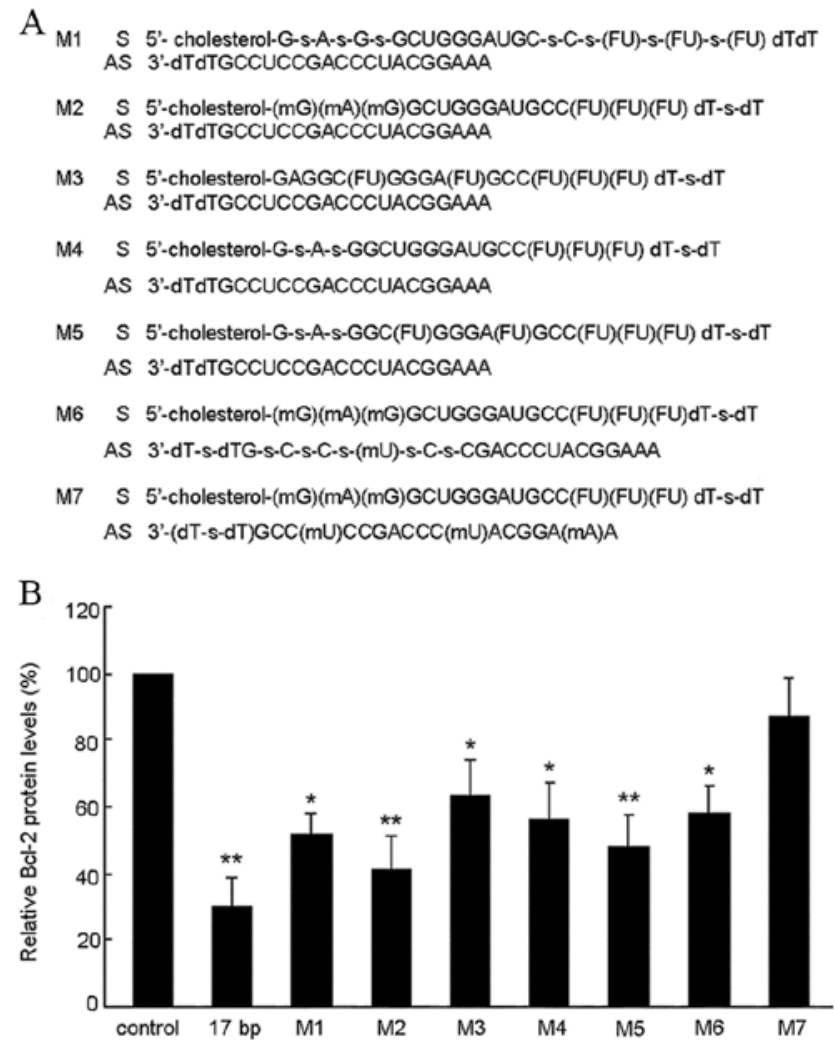

Figure 3. In vitro gene silencing activity of chemically modified 17 bp asiRNA. (A) The sequences and structures of chemically modified 17 bp asiRNAs. Lowercase $\mathrm{s}$ between nucleotides, phosphorothioate modification; lowercase m, 2'-O-methylation modification; FU, 2'-fluoro-uridine modification. (B) Effect of chemically modified $17 \mathrm{bp}$ asiRNAs on the downregulation of the expression of the Bcl-2 protein. Unmodified or chemically modified $17 \mathrm{bp}$ asiRNA were transfected into HeLa B2 cells for $72 \mathrm{~h}$. The Bcl-2 protein levels were analyzed by flow cytometric assay. The control group was cells only treated with transfection reagent. ${ }^{*} \mathrm{P}<0.05 ;{ }^{* *} \mathrm{P}<0.01$.

Incubation with FBS time (h)

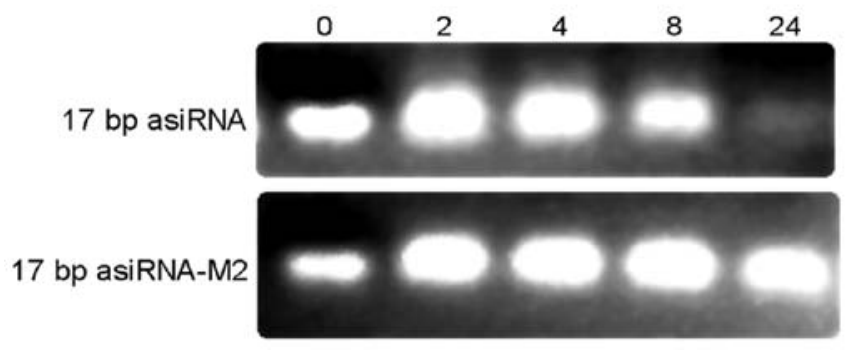

Figure 4. Comparison of the serum stability of $17 \mathrm{bp}$ asiRNA and chemically modified 17 bp asiRNA-M2 in vitro. Unmodified and modified 17 bp asiRNA was incubated at $37^{\circ} \mathrm{C}$ in FBS for 2, 4,8 and $24 \mathrm{~h}$. Each sample was loaded onto a $2 \%$ agarose gel and visualized by ethidium bromide staining.

showed the best gene silencing effect among all the chemically modified asiRNAs. There was no significant difference between the 17 bp asiRNA and 17 bp asiRNA-M2 groups ( $\mathrm{P}>0.05)$.

Serum stability of chemically modified and unmodified asiRNA in vitro. To evaluate the stability of the asiRNAs in serum, $17 \mathrm{bp}$
asiRNA and 17 bp asiRNA-M2 were incubated in FBS and separated by gel electrophoresis and subsequently visualized by ethidium bromide staining. As shown in Fig. 4, unmodified $17 \mathrm{bp}$ asiRNA degraded rapidly in the presence of serum, with the band becoming undetectable at $24 \mathrm{~h}$. By contrast, there was a little detectable degradation of $17 \mathrm{bp}$ asiRNA-M2, even after $24 \mathrm{~h}$. The results showed that the chemically modified $17 \mathrm{bp}$ asiRNA-M2 enhanced nuclease resistance of the asiRNA and significantly increased its serum stability.

Distribution of 17 bp asiRNA-M2/PDE complex in vivo. The effectiveness of siRNA therapeutics is hindered by limited blood stability and the successful delivery system of siRNA in vivo. In our previous study, a micelle PDE was successfully used to deliver siRNA (22). In this study, to investigate the real-time bio-distribution and the durability of a chemically modified 17 bp asiRNA either naked (17 bp asiRNA-M2) or delivered by PDE (17 bp asiRNA-M2/PDE complex) in vivo, we intravenously administered naked Cy5.5-labeled 17 bp asiRNA-M2 or Cy5.5-labeled 17 bp asiRNA-M2/PDE complex to HuH-7 tumor-bearing mice. As shown in Fig. 5A, the $17 \mathrm{bp}$ asiRNA-M2/PDE complex-treated mice exhibited a substantial fluorescence intensity (over their whole bodies) for up to $48 \mathrm{~h}$, while the fluorescence intensity in the naked 17 bp asiRNAM2-treated mice was significantly reduced at $24 \mathrm{~h}$. As shown in Fig. 5B and C, fluorescence signals were detected in all organs and tumors. Compared with the naked 17 bp asiRNA-M2treated group, the $17 \mathrm{bp}$ asiRNA-M2/PDE complex-treated group showed a stronger signal, which was particularly obvious in tumors.

Treatment with chemically modified asiRNA targeting bcl-2 inhibits the growth of tumors in vivo. To investigate the therapeutic effect of $17 \mathrm{bp}$ asiRNA-M2 on the growth of tumors in vivo, $\mathrm{H} 22$ tumor cells were subcutaneously inoculated into Kunming mice. The mice were treated with normal saline, CTX, naked 17 bp asiRNA-M2, PDE and 17 bp asiRNAM2/PDE complexes continuously for 14 days, respectively. The volumes of the tumors were assessed every five days. Twenty days after the treatment, the inhibitory rate of the $17 \mathrm{bp}$ asiRNA-M2/PDE complex-treated group was $64.3 \%$ $(\mathrm{P}<0.01)$ compared with the normal saline group, while that of the naked 17 bp asiRNA-M2-treated group was only $32.4 \%$ (P>0.05) (Fig. 6A). The results demonstrated that the $17 \mathrm{bp}$ asiRNA-M2/PDE complex significantly inhibited the H22 tumor growth in vivo.

BGC 803 gastric tumor cells were subcutaneously inoculated into $\mathrm{BLBA} / \mathrm{c}$ nude mice. The mice were treated with normal saline, CTX, PDE and 17 bp asiRNA-M2/PDE complexes continuously for 14 days, respectively. On day 18 post the initiation of the treatment, the mice were sacrificed and the tumors were excised, measured and weighed. As shown in Fig. 6B and C, the tumor inhibitory rate of $17 \mathrm{bp}$ asiRNA-M2/ PDE complex-treated group was $68.2 \%(\mathrm{P}<0.01)$ by volume and $64.3 \%(\mathrm{P}<0.01)$ by weight compared with the normal saline group. When compared with the PDE group, the inhibitory rate of $17 \mathrm{bp}$ asiRNA-M2/PDE complex-treated group was $60.6 \%$ $(\mathrm{P}<0.01)$ by volume and $53.1 \%(\mathrm{P}<0.01)$ by weight. The results suggested that 17 bp asiRNA-M2/PDE complexes were similarly effective in inhibiting BGC 803 tumor growth in vivo. 
A
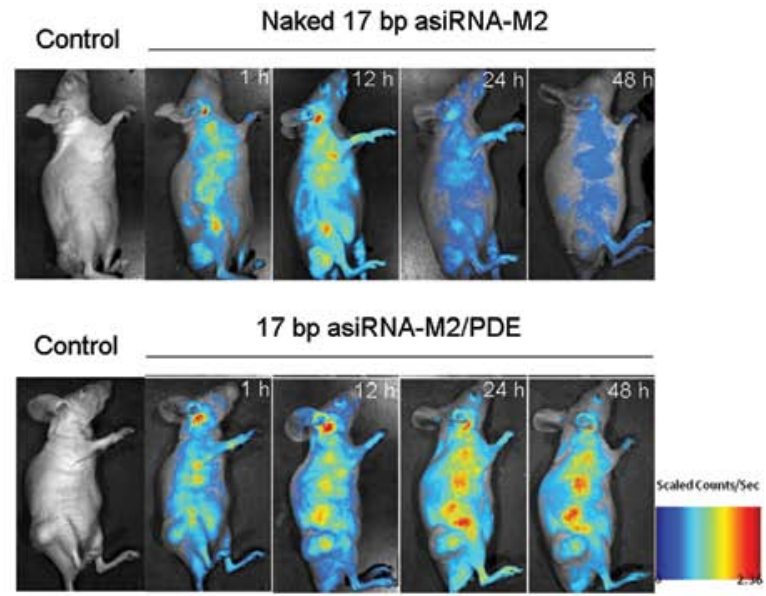

B

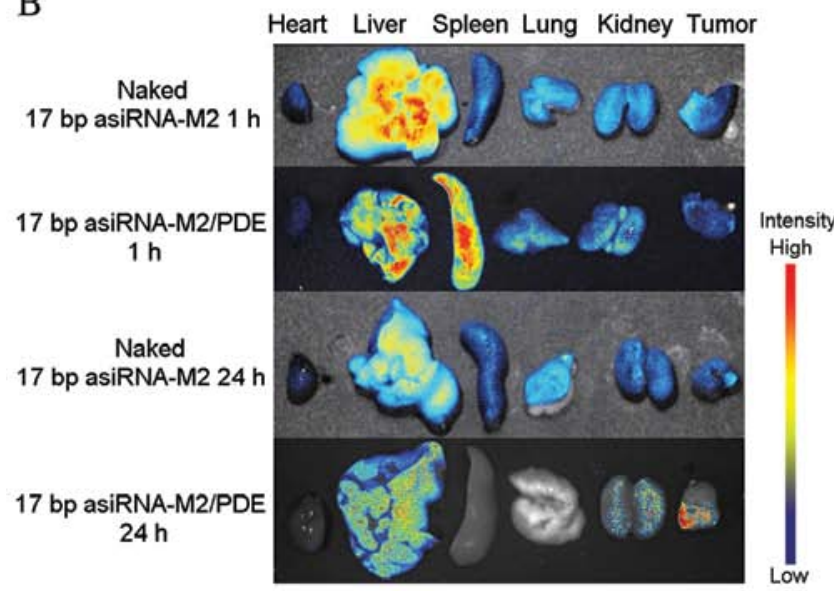

C

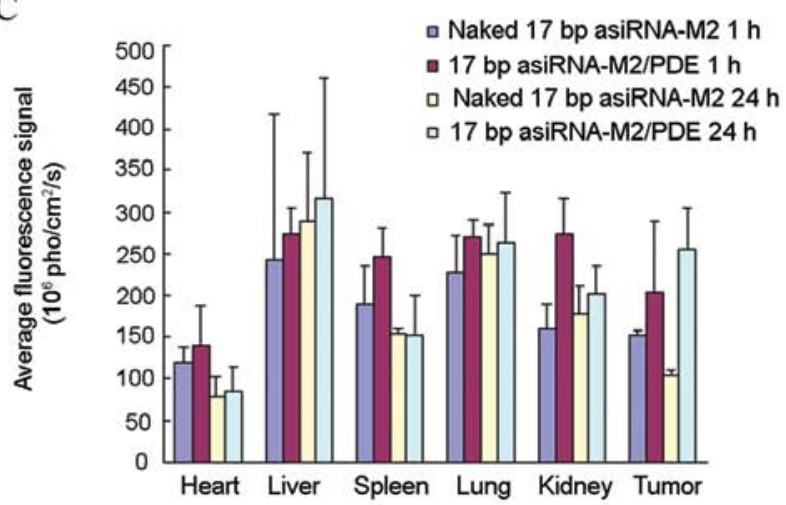

Figure 5. In vivo 17 bp asiRNA-M2/PDE complex distribution. (A) Whole-body distribution of $17 \mathrm{bp}$ asiRNA-M2/PDE complex in vivo. Mice were injected intravenously with $40 \mu \mathrm{g}$ Cy5.5 labeled $17 \mathrm{bp}$ asiRNA-M2 either naked or mixed with PDE. (B) In vivo distribution of naked 17 bp asiRNA-M2 or 17 bp asiRNAM2/PDE complexes in the organs and tumors. (C) Quantitative analysis of the distribution of naked 17 bp asiRNA-M2 or 17 bp asiRNA-M2/PDE complex in isolated organs and tumors (mean $\pm \mathrm{SD}, \mathrm{n}=3$ ).

\section{Discussion}

In this study, we designed and synthesized asiRNAs targeting bcl-2 with truncated siRNA backbone structures with duplex regions shorter than $19 \mathrm{bp}$ and the results showed that $17 \mathrm{bp}$ asiRNA downregulated bcl-2 expression more effectively than that of symmetrical siRNA and its other asymmetrical
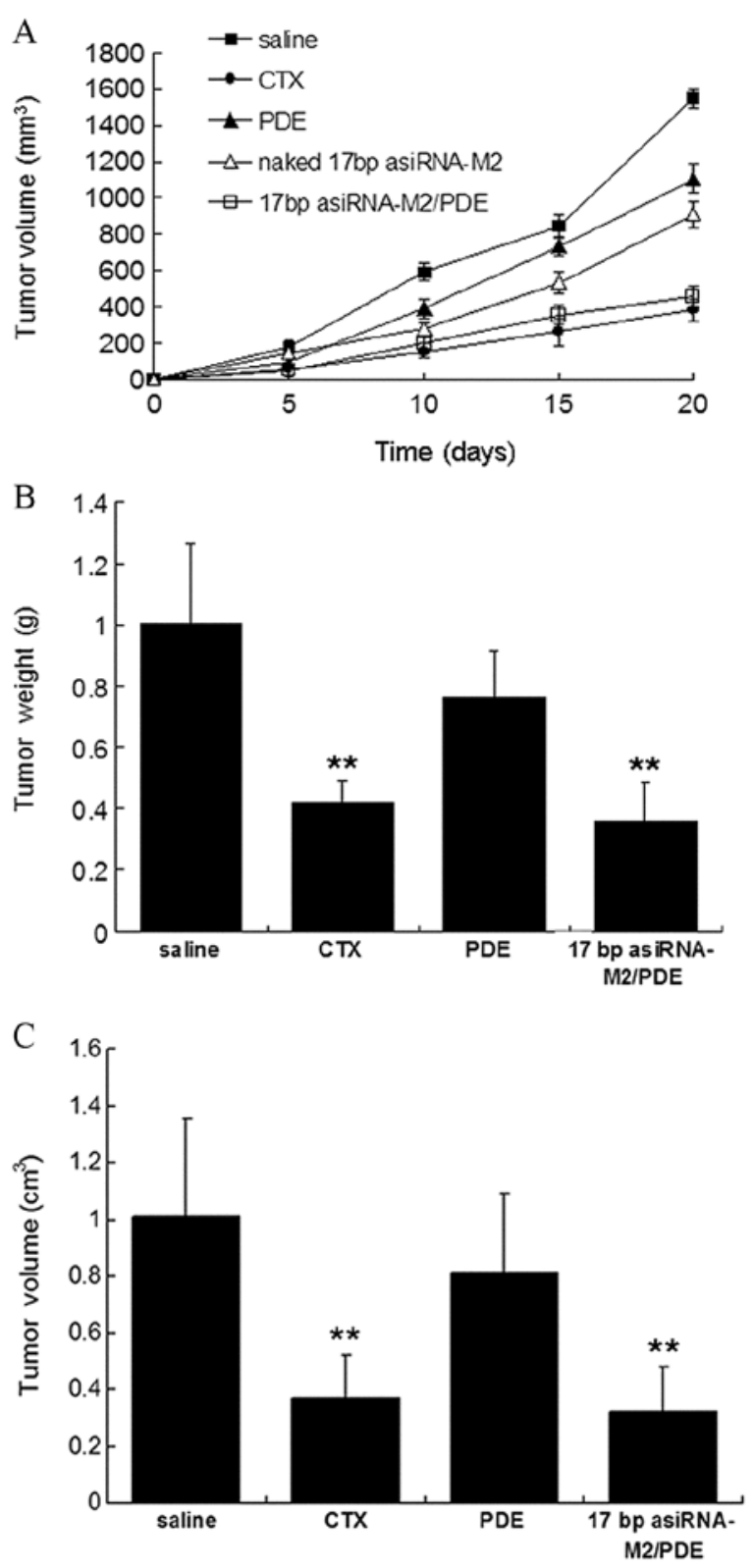

Figure 6. Effects of the $17 \mathrm{bp}$ asiRNA-M2/PDE complex on the growth of $\mathrm{H} 22$ and BGC 803 tumors in vivo. (A) The growth curves of $\mathrm{H} 22$ tumors in different groups after treatment (mean $\pm \mathrm{SD}, \mathrm{n}=10$ ). Tumors were measured every five days after the treatment and the tumor volumes were calculated. (B and C) The average tumor weight and tumor volume in different groups are shown $($ mean $\pm \mathrm{SD}, \mathrm{n}=6){ }^{* * *} \mathrm{P}<0.01$.

counterparts. Previous studies have demonstrated that asiRNA is effective in silencing the target gene expression. Sun et al (12) designed asymmetric RNA duplexes of various lengths with overhangs at the $3^{\prime}$ and $5^{\prime}$ ends of the antisense strand to target CTNNB1 and $15 \mathrm{bp}$ asiRNA showed more potent silencing efficacy. Chang et al (13) reported that two structures with duplexes shorter than $19 \mathrm{bp}, 17+2 \mathrm{~A}$ and $16+3 \mathrm{~A}$, efficiently reduced the expression of lamin $\mathrm{A} / \mathrm{C}$, survivin and integrin mRNAs. Our data in this study are consistent with these reports and demonstrate that a symmetrical scaffold of siRNA is not necessarily required for the activation of RNAi. However, the optimal structure of asiRNA may depend on sequences and target genes. 
Off-target gene silencing is a major obstacle to the therapeutic application of siRNA. One mechanism of off-target gene silencing is the incorporation of sense strand into RISC (11). Previous studies have demonstrated that the strand selection of siRNAs depends on the thermodynamic stabilities of their 5 '-ends $(23,24)$. However, Sano et al $(25)$ reported that terminal structures of siRNAs duplexes are the predominant determinants of the strand selection rather than thermodynamic asymmetry at the ends of siRNAs. In the current study, we demonstrated that asiRNA with asymmetric RNA duplexes significantly reduced the off-target gene silencing mediated by the sense strand, which may be a possible reason of the potent RNAi activity of asiRNA. Our results further demonstrated that structural asymmetry is another crucial determinant of RISC loading and provide useful guidelines for optimal siRNAs design.

The therapeutic application of siRNA has been hampered due to its limited stability, poor cellular uptake and the lack of an appropriate delivery method in vivo $(26,27)$. Chemical modification is the principal strategy used to improve the nuclease resistance of siRNA. Sugar modification at the 2'-OH and phosphate linkage modification have been demonstrated to improve the stability of siRNA $(16,17,28)$ and conjugation of cholesterol at termini of the strands could enhance the siRNA cell uptake $(29,30)$. In this study, we introduced 2'-O-Me, 2'-FU, phosphorothioate and cholesterol modification to $17 \mathrm{bp}$ asiRNA and evaluated their gene silencing activity in vitro. Although the activity of all the chemically modified $17 \mathrm{bp}$ asiRNAs was affected by the modification, 17 bp asiRNA-M2 retained comparable activity comparing with its original counterpart and was the most active one among the others. Furthermore, 17 bp asiRNA-M2 was shown to be more stable than unmodified asiRNA in vitro. Our data are consistent with previous reports that the stability of chemically modified siRNA can markedly improve, while the gene silencing activity usually decreases $(16,28)$. Generally, increasing interference efficiency is not the main objective of chemical modification and maintaining the potency of unmodified siRNA while increasing its serum stability is sufficient. In our study, although the silencing activity of modified $17 \mathrm{bp}$ asiRNA-M2 was slightly reduced with no statistical significance, its stability was obviously improved. However, for systemic application of siRNA in vivo, chemical modification is not enough because most target cells are not permeable to naked siRNAs. A number of approaches have been developed to deliver siRNA to the targeted cells after systemic injections $(19,20)$. In this study, the PDE which was developed in our previous study for siRNA delivery was used to deliver 17 bp asiRNA-M2 targeting bcl-2. The in vivo distribution analysis showed that the $17 \mathrm{bp}$ asiRNA-M2/PDE complex maintained longer fluorescence signals in the whole body and stronger fluorescence intensity in the organs and tumors compared with the naked 17 bp asiRNA-M2 (Fig. 5). These results demonstrated the high stability of the $17 \mathrm{bp}$ asiRNA-M2/PDE complex in vivo. Compared with the naked asiRNA, significant signals were detected in the tumor by use of PDE $24 \mathrm{~h}$ after injection, suggesting $17 \mathrm{bp}$ asiRNA-M2 could be delivered to tumor by PDE-mediated systemic administration. The average particle size of the $17 \mathrm{bp}$ asiRNA-M2/PDE complex was approximately $147 \mathrm{~nm}$ (data not shown), so the nano-sized complex may accumulate in the tumors via the enhanced permeability and retention (EPR) effect $(31,32)$. In addition, endostatin can bind to membranes containing acidic phospholipids, phosphatidylserine (PS) or phosphatidylglycerol (PG) and many tumors cells have been found to have aberrantly exposed PS-rich domains on the cell surface (33-35), which may be another possible mechanism for tumor accumulation of the complexes. Furthermore, the 17 bp asiRNA-M2/PDE complex was shown to result in significant tumor regression without toxic or side-effects in vivo.

In conclusion, synthesized $17 \mathrm{bp}$ asiRNA was more potent in inhibiting bcl-2 expression and tumor cell proliferation in vitro. When 17 bp asiRNA was appropriately modified and delivered by a suitable system, it proved to be very stable and significantly inhibited tumor growth in vivo. Our study suggests that asiRNA targeting bcl-2 may be a promising approach for cancer therapy.

\section{Acknowledgements}

The present study was supported by the following grants: BK2011271, BK2011044 and BY2012185 from the Foundation of Jiangsu Province, China, 2009ZX09103-635 of the National Science and Technology Major Projects from the Ministry of Science and Technology of China and KF-GN-201204 from the State Key Laboratory of Pharmaceutical Biotechnology, Nanjing University, to G.-X.X.; 31070959 and NSFC/RGC Joint Research Scheme 30931160433 from the National Natural Science Foundation of China, RFDP 20100091110016 and Fundamental Research Funds for the Central Universities 1094020806 from the State Educational Ministry of China and BK2011014 from the Natural Science Foundation of Jiangsu Province, China to J.-J.W. The study was also supported by a grant 9112020802 of '985 Project' from Nanjing University to J.-J.W.

\section{References}

1. Adams JM and Cory S: The Bcl-2 protein family: arbiters of cell survival. Science 281: 1322-1326, 1998.

2. Kaiser U, Schilli M, Haag U, Neumann K, Kreipe H, Kogan E and Havemann K: Expression of bcl-2-protein in small cell lung cancer. Lung Cancer 15: 31-40, 1996.

3. Kobayashi S, Iwase H, Ito Y, et al: Clinical significance of bcl-2 gene expression in human breast cancer tissues. Breast Cancer Res Treat 42: 173-181, 1997.

4. Kaklamanis L, Savage A, Whitehouse R, et al: bcl-2 protein expression: association with p53 and prognosis in colorectal cancer. Br J Cancer 77: 1864-1869, 1998.

5. Sinicrope FA, Ruan SB, Cleary KR, Stephens LC, Lee JJ and Levin B: bcl-2 and p53 oncoprotein expression during colorectal tumorigenesis. Cancer Res 55: 237-241, 1995.

6. Bronner MP, Culin C, Reed JC and Futh EE: The bcl-2 protooncogene and the gastrointestinal epithelial tumor progression model. Am J Pathol 146: 20-26, 1995.

7. Miyake H, Hara I, Yamanaka K, Gohji K, Arakawa S and Kamidono S: Overexpression of bcl-2 enhances metastatic potential of human bladder cancer cells. Br J Cancer 79: 1651-1656, 1999.

8. Elbashir SM, Harborth J, Lendeckel W, Yalcin A, Weber K and Tuschl T: Duplexes of 21-nucleotide RNAs mediate RNA interference in cultured mammalian cells. Nature 411: 494-498, 2001.

9. Zamore PD, Tuschl T, Sharp PA and Bartel DP: RNAi: doublestranded RNA directs the ATP-dependent cleavage of mRNA at 21 to 23 nucleotide intervals. Cell 101: 25-33, 2000.

10. Jackson AL and Linsley PS: Noise amidst the silence: off-target effects of siRNAs? Trends Genet 20: 521-524, 2004.

11. Clark PR, Pober JS and Kluger MS: Knockdown of TNFR1 by the sense strand of an ICAM-1 siRNA: dissection of an offtarget effect. Nucleic Acids Res 36: 1081-1097, 2008. 
12. Sun X, Rogoff HA and Li CJ: Asymmetric RNA duplexes mediate RNA interference in mammalian cells. Nat Biotechnol 26: 1379-1382, 2008.

13. Chang CI, Yoo JW, Hong SW, et al: Asymmetric shorter-duplex siRNA structures trigger efficient gene silencing with reduced nonspecific effects. Mol Ther 17: 725-732, 2009.

14. Jo S, Hong SW, Yoo JW, Lee CH, Kim S, Kim S and Lee DK: Selection and optimization of asymmetric siRNA targeting the human c-MET gene. Mol Cells 32: 543-548, 2011.

15. Watts JK, Deleavey GF and Damha MJ: Chemically modified siRNA: tools and applications. Drug Discov Today 13: 842-855, 2008.

16. Braasch DA, Jensen S, Liu Y, Kaur K, Arar K, White MA and Corey DR: RNA interference in mammalian cells by chemically-modified RNA. Biochemistry 42: 7967-7975, 2003.

17. Amarzguioui M, Holen T, Babaie E and Prydz H: Tolerance for mutations and chemical modifications in a siRNA. Nucleic Acids Res 31: 589-595, 2003.

18. Love KT, Mahon KP, Levins CG, et al: Lipid-like materials for low-dose, in vivo gene silencing. Proc Natl Acad Sci USA 107: 1864-1869, 2010

19. Park K, Lee MY, Kim KS and Hahn SK: Target specific tumor treatment by VEGF siRNA complexed with reducible polyethyleneimine-hyaluronic acid conjugate. Biomaterials 31 : 5258-5265, 2010.

20. Davis ME, Zuckerman JE, Choi CH, et al: Evidence of RNAi in humans from systemically administered siRNA via targeted nanoparticles. Nature 464: 1067-1070, 2010.

21. Fu GF, Lin XH, Han QW, et al: RNA interference remarkably suppresses bcl-2 gene expression in cancer cells in vitro and in vivo. Cancer Biol Ther 4: 822-829, 2005.

22. Guo JJ, Yin Y, Zhang CD, Wang JJ and Xu GX: Antitumor effects of liposome-mediated siRNA and asymmetric shorterduplex siRNA suppressing VEGF gene expression. Pharm Clin Res 19: 489-494, 2011.

23. Schwarz DS, Hutvágner $\mathrm{G}, \mathrm{Du} \mathrm{T}, \mathrm{Xu} \mathrm{Z}$, Aronin $\mathrm{N}$ and Zamore PD: Asymmetry in the assembly of the RNAi enzyme complex. Cell 115: 199-208, 2003.

24. Ameres SL, Martinez J and Schroeder R: Molecular basis for target RNA recognition and cleavage by human RISC. Cell 130: $101-112,2007$.
25. Sano M, Sierant M, Miyagishi M, Nakanishi M, Takagi Y and Sutou S: Effect of asymmetric terminal structures of short RNA duplexes on the RNA interference activity and strand selection. Nucleic Acids Res 36: 5812-5821, 2008.

26. White PJ: Barriers to successful delivery of short interfering RNA after systemic administration. Clin Exp Pharmacol Physiol 35: 1371-1376, 2008.

27. Aagaard L and Rossi JJ: RNAi therapeutics: principles, prospects and challenges. Adv Drug Deliv Rev 59: 75-86, 2007.

28. Chiu YL and Rana TM: siRNA function in RNAi: a chemical modification analysis. RNA 9: 1034-1048, 2003.

29. Lorenz C, Hadwiger P, John M, Vornlocher HP and Unverzagt C: Steroid and lipid conjugates of siRNAs to enhance cellular uptake and gene silencing in liver cells. Bioorg Med Chem Lett 14: 4975-4977, 2004

30. Soutschek J, Akinc A, Bramlage B, et al: Therapeutic silencing of an endogenous gene by systemic administration of modified siRNAs. Nature 432: 173-178, 2004.

31. Maeda H, Wu J, Sawa T, Matsumura Y and Hori K: Tumor vascular permeability and the EPR effect in macromolecular therapeutics: a review. J Control Release 65: 271-284, 2000.

32. Maeda H, Bharate GY and Daruwalla J: Polymeric drugs for efficient tumor-targeted drug delivery based on EPR-effect. Eur J Pharm Biopharm 71: 409-419, 2009.

33. Zhao H, Jutila A, Nurminen T, Wickström SA, Keski-Oja J and Kinnunen PK: Binding of endostatin to phosphatidylserinecontaining membranes and formation of amyloid-like fibers. Biochemistry 44: 2857-2863, 2005.

34. Ran S, Downes A and Thorpe PE: Increased exposure of anionic phospholipids on the surface of tumor blood vessels. Cancer Res 62: 6132-6140, 2002.

35. Utsugi T, Schroit AJ, Connor J, Bucana CD and Fidler IJ: Elevated expression of phosphatidylserine in the outer membrane leaflet of human tumor cells and recognition by activated human blood monocytes. Cancer Res 51: 3062-3066, 1991. 